\title{
Julgamento Conforme o Estado do Processo (TEMAS POLEMICOS)
}

\author{
Rogério Lauria Tucci \\ Professor de Direito Processual da Faculdade \\ de Direito da USP
}

\begin{abstract}
S U M A R I O : 1. Delimitação dos contornos do instituto. 2. Momentos da extinção do processo sem julgamento do mérito. 3. Atecnia das disposições referentes ao julgamento conforme o estado do processo. 4. Sentença homologatória como sentença de mérito. 5. Inadmissibilidade de condenação em honorários ađvocatícios a alta de apelação adesiva do réu. 6. Conjugação do disposto nos artigos 319 e 330 , inciso Ir, do Código de Processo Civil. 7. Consequiências da revelia em sentido estrito na reconvenção. 8. Conclusões.
\end{abstract}

\section{Delimitação dos contornos do instituto}

É o julgamento conforme o estado do processo, sem dúvida alguma, uma das mais importantes inovaçōes introduzidas pelo Código de 1973 no Direito Processual Civil Brasileiro.

Resultado da conjugação parcial de modelos alienígenas, ganha, todavia, notável originalidade, que o coloca entre as principais instituições da moderna ciência processual, seguramente orientado à proclamada necessidade de «simplificação do processo, a par da celeridade na sua conclusão, com preciosa economia de tempo, atos e despesas, a fim de que a justiça possa ser melhor ministrada, inclusive mais perfeita e rapidamente» (cf., a respeito de institutos afins, nosso Do julgamento conforme o estado do processo, $2^{\text {a }}$ ed., São Paulo, 1982, pág. 33).

$\mathrm{E}$ apresenta-se, notoriamente, dividido em duas espécie, a saber: a) a atinente ao objeto formal do processo, consubstanciada no por nós denominado julgamento segundo o estado dos autos e a que corresponde, na terminologia legal, a extinção do processo sem julgamento do mérito (cf. artigo 329, primeira parte, combinado com o 267) ; e b) a referente ao objeto material do processo, em que se traduz o julgamento antecipado da lide, ou seja, do meritum causae (cf., ainda, artigos 329, segunda parte, e 269, incisos II a V).

Não abrange, portanto, como, de maneira equívoca, faz crer aludida Codificação - ao secionar o Capítulo V, do Título VIII («Do procedimento ordinário») do Livro I («Do processo de conhecimento»), em «Da extinção do processo», «Do julgamento antecipado da lide» € «Do saneamento do processo», - a decisão mediante a qual o juiz declara saneado o processo (artigo 331). 
Esta, na realidade, só deve ser proferida, quando seja caso de julgamento conforme o estado do processo, com o qual (data venia dos autorizados processualistas que entendem de modo contrário) não pode ser confundida.

Como tivemos, já, oportunidade de acentuar, na indicada monografia, à pág. 282, nota 2 , diferentemente do expendido por JOSÉ CARLOS BARBOSA MOREIRA, O novo processo civil brasileiro, $3^{\text {a }}$ ed., Rio de Janeiro, 1978, vol. I, pag. 153, «e outros igualmente ilustres juristas especializados em Direito Processual (e. g., EGAS DIRCEU MONIZ DE ARAGÃO, 0 julgamento conforme o estado do processo, cit., p.13; JOSEE JOAQUIM CALMON DE PASSOS, Comentários ao Código de Processo Civil, cit., v.3, p.594; MOACYR AMARAL SANTOS, Primeiras linhas de Direito processual civil, cit., v. 2, p. 232), entendemos que a decisão de saneamento do processo não constitui julgamento conforme o estado deste, que se consubstancia numa sentença, mas, apenas, ato decisório de natureza interlocutória em que o juiz o declara livre de obstáculos para a resolugão do mérito, ainda inoportuna (v., a tal propósito, $\mathrm{n}^{\mathrm{s}} \mathrm{s} 49$, supra, e 91 , infra; e, com a mesma opinião, ALEXANDRE DE PAULA, Código de Processo Civil anotado, cit., v.2, p.177; ALCIDES DE MENDONÇA LIMA, As providências preliminares no Código de Processo Civil brasileiro de 1973, cit., p. 95)».

Nesse sentido, por igual, têm-se manifestado nossos Pretórios, tal como patenteia THEOTóNIO NEGRÃO, Código de Processo Civil e legislação processual em vigor, $11^{\text {a }}$ ed., São Paulo, 1982, pág. 135, nota 1 ao art. 331: Rev. For., 254, pag. 198; Rev. do Tribs., vols. 507/147, 471/171; Rev. de Jurispr. do TJESP, vol. 44, pág. 233; Julgados do TJESP, vols. e págs. 49/43, 43/153, 41/109 e 136, 39/305, 34/307 e $335,33 / 392$.

\section{Momentos da extinção do processo sem julgamento do mérito}

- O segundo tema considerável polêmico a ser enfrentado, neste estudo acerca do julgamento conforme o estado do processo, é o alusivo aos momentos em que o juiz pode pôr-lhe termo sem exame do mérito da causa.

Nosso entendimento, conhecido, é o de que o julgamento segundo o estado dos autos pode ter lugar em todo o desenrolar do procedimento, ou seja, desde o aforamento da ação, «tanto que a petição seja despachada pelo juiz, ou simplesmente distribuída, onde houver mais de uma vara» (cf. artigo 263, primeira parte), até o proferimento da sentença de mérito (cf. artigo $267, \S 3^{\circ}$, de aplicação generosamente extensiva).

Não havendo dúvida, no derradeiro aspecto, quanto à relatividade da eficácia preclusiva do ato decisório de saneamento do processo, manifesta afigura-se, todavia, a discrepância doutrinária a respeito 
de constituir o indeferimento da petição inicial um ato decisório de extinção do processo.

Entre os que assim não o consideram alinham-se principalmente, EGAS DIRCEU MONIZ DE ARAGÃO, Comentários ao Código de Processo Civil, 2a ed., Rio de Janeiro, 1976, vol. II pág. 488, sustentando não constituir o indeferimento liminar da petição inicial caso de extinção, mas de inadmissibilidade de formação do processo; e HELLIO TORNAGHI, Comentários ao Código de Processo Civil, São Paulo, 1975, vol. II, págs. 330/331 (inobstante possa ser tido como dúbio o seu posicionamento, como procuram mostrar o mesmo MONIZ DE ARAGÃO, op. et vol. cit., pág. 489, nota 3; e PONTES DE MIRANDA, Comentários ao Código de Processo Civil, $2^{\text {a }}$ ed., Rio de Janeiro, 1979, tomo III, págs. 604/611).

Já o saudoso tratadista pátrio, ultimamente citado, LUtS ANTÔNIO DE ANDRADE, Aspectos e inovações do Código de Processo Civil, Rio de Janeiro, 1974, pags. 102./103 e 117; SÉRGIO SAHIONE FADEL, Código de Processo Civil comentado, $4^{a}$ ed., Rio de Janeiro, 1981, vol. I, pág. 441 (apesar da restrição feita ao texto legal); e MARCOS AFONSO BORGES, Comentários ao Código de Processo Civil, São Paulo, 1974/1975, vol. I, pág. 256, entre outros, afiançam que essa é, realmente, uma das modalidades de extinção do processo sem julgamento do mérito.

Expressa-o, aliás, com todas as letras, o artigo 267, inciso I, do vigente Código de Processo Civil, verbis: «Extingue-se o processo, sem julgamento do mérito: I - quando o juiz indefirir a peticão inicial» (grifado).

E, como assevera LUIS ANTONIO DE ANDRADE, in op. et loccit., "Andou certo o legislador de 1973. A instauração da relação processual na verdade se inicia com o despacho na petição inicial. Ou, mesmo, antes - quando esta apenas distribuída - se na comarca houver mais de uma vara, pois nesse caso e desde esse momento nasce para o juiz a obrigação de despachá-la, mandando, ou não, citar o réu. Do contrário ficaria ao arbítrio do órgão julgador a fixação temporal da instauração do processo. Inspirou-se o codificador, ao ditar a nova regra, ao que parece, na lei portuguesa, segundo a qual a ação é considerada proposta logo que recebida na secretaria a respectiva petição inicial (CPC, art. 267)».

Essa, outrossim, é a tônica de julgamento das Câmaras Cíveis do Tribunal de Justiça do Estado de Mato Grosso, cuja ementa, no particular é a seguinte: «Extingue-se o processo, sem julgamento do mérito por ter sido indeferida a inicial» (grifado).

De resto, o próprio MONIZ DE ARAGÃO, op. et. vol. cit., pág. 431, não foge a que o legislador brasileiro, ao solucionar «o problema em consonância com a realidade e acorde com a melhor doutrina», teve em vista que, ao «iniciar a formação do processo, o fato de propor a demanda já produz efeitos». 
Ora, um processo cuja formagão tenha sido iniciada (cf. o mesmo eminente autor, à pág. 432 , «...o ato inicial de formação do processo se completa com o despacho oposto pelo juiz à petição inicial») só pode ser trancada mediante sentença de extinção.

Vem aqui, a tal propósito, lição de PONTES DE MIRANDA, op. et tomo cit., págs. $611 / 612$, segundo a qual, começando o progresso pela iniciativa da parte, como, acertadamente, consta do artigo 262, o decisório de indeferimento liminar da petição inicial faz extingui-lo, mesmo que o réu não tenha sido, ainda, citado: "Ai, a despeito do indeferimento, angulariza-se a relação jurídica processual, que começa com a iniciativa do autor» (textual, e com nossa conhecida restrição, válida também para transcrição anterior, à concepção do processo como relação jurídica processual).

\section{Atecnia das disposições referentes ao julgamento conforme o es- tado do processo}

Relativamente ao indeferimento da petição inicial, há outra situação que faz por merecer idêntico destaque.

$\mathrm{Na}$ enumeração dos respectivos casos, expressa o artigo 295 do Código de Processo Civil o atinente à verificação, desde logo da decadência ou da prescrição (esta, por certo, quando referente a direitos não patrimoniais, cf. artigo $219, \S 5^{\circ}$ ).

Acontece que o artigo 267, inciso I, elenca o indeferimento da peça vestibular da ação entre as hipóteses da extinção do processo sem julgamento do mérito, mas o versado diz com a composicão da lide, nos termos do artigo 269, inciso IV

Esse derradeiramente apontado dispositivo - acentuamos no Do julgamento cit., pág. 225 , - pôs termo à controvérsia ocorrente entre os jurisperitos, na vigência do Código de Processo Civil de 1939, «estatuindo constituirem a decadência e a prescrição objeto de apreciação num juízo de mérito, ou seja, mediante pronunciação de julgamento antecipado da lide, ou sentenca definitiva proferida ao final da instrução da causa, ambos momentos do procedimento ordinário - aquele integrante da fase saneadora, e esta da fase decisória - e dos quais resulta o encerramento normal do processo, com a composição do litígio submetido à apreciação do órgão jurisdicional» (v., em idêntico senso, a XXVIa. Conclusão do Simpósio de Processo Civil, realizado no ano de 1975 em Curitiba).

Ademais, e como, com acuidade, observa JOSÉ FREDERICO MARQUES, Manual de Direito Processual Civil, São Paulo, 1974, vol. II, pág. 162, a patentear uma exceção às regras procedimentais focadas, «esse julgamento antecipado da lide pode ser proferido até mesmo in initio litis», mediante sentença definitiva à qual se aplicam os artigos 455 a 466 do Código de Processo Civil vigente. 
Isso significa, também, que, ao contrário do entendimento manifestado por eminentes processualistas, a indicação do artigo 329 , segunda parte, ao artigo 269, incisos II a V, revela a previsão de julgamento antecipado da lide, não só nas circunstâncias alvitradas no artigo 330, como, por igual, em se tratando de reconhecimento da procedência do pedido, pelo réu, de transação, de pronunciação da decadência ou da prescrição e de renúncia, pelo autor, ao direito sobre que se funda a ação (v., a respeito, PONTES DE MIRANDA, op. cit., 1975, tomo VI, pags. $355 / 356$; LUİS EULĀLIO DE BUENO VIDIGAL, Comentários ao Código de Processo Civil, São Paulo, 1974, vol. VI, pág. 163; HUMBERTO THEODORO JÚNIOR, Processo de conhecimento, Rio de Janeiro, 1978, tomo II, pág. 506, ARTUR OSCAR DE OLIVEIRA DEDA, «Da formação, da suspensão e da extinção do processo», in Revista Forense, Rio de Janeiro, 1978, vol. 262, pág. 60; ARRUDA ALVIM, «Dogmática jurídica e o novo Código de Processo Civil», in mesma Revista, 1975, vol. 252, pág. 60, nota 95; Arq. Jud., vol. 69, pág. 112; Rev. For., vol. 96, pág. 323; Rev. dos Tribs., vols. e pags. $432 / 225,405 / 202,381 / 145,353 / 215$ ).

O ilustre autor e magistrado paulista, no estudo ultimamente mencionado, anota, com precisão - inobstante distinguindo entre os atos compositivos do litígios, pelas partes, e a definição da lide, efetiva e intrisecamente, pelo juiz, - que «No art. 329 , fala a lei que a lide — se não tiver sido extinto o processo, sem julgamento de mérito (aplicação do art. 267) - será extinta, com julgamento de mérito, mercê da aplicação dos incs. II — , do art. 269. Em rigor, nas hipóteses do art. 269, II a $\mathrm{V}$, quando o art. 330 se refere que o juiz declarará extinto o processo, devemos observar que, para tais casos, o legislador dixit minus quam voluit. Efetivamente em tais casos extingue-se, não só o processo, mas também a lide» (com os primeiros grifos nossos).

Se não isso - permitimo-nos aduzir, - indisfarçável defeito de técnica, ao cumular, no artigo 329 , casos de extinção do processo sem ou com julgamento do mérito, e alvitrar, no artigo 330 , outros, exclusivamente, de julgamento antecipado da lide.

Este, enfim, consistente num prévio juízo de mérito, encontra-se em ambos os dispositivos, com as características determinadas em cada uma das diferentes situações. E, revela-se, sempre, numa sentença definitiva que, com a preclusão dos prazos para recursos, se vê coberta pela coisa julgada material.

Prova eloqüente dessa derradeira afirmativa dá-nos a própria Codificação processual civil em vigor, ao ter, expressamente, no artigo 584, inciso III, a sentença homologatória de transação como título executivo judicial.

\section{Sentença homologatória como sentença de mérito}

É que a homologação em casos que, tais, não se faz «automática, mas, pelo contrário, necessariamente alomática, isto é, perqui- 
ridora dos requisitos reclamados pelo ato homologando» cf. Do Julgamento cit. pág. 223, com a lembrança, complementar, do poder concedido ao juiz, nos artigos 125 , inciso III, e 129, de repressão à atuação contrária à dignidade da justiça e de coibição à prática de ato ilícito ou da consecução de fim proibido pela lei).

Daí, inclusive, a possibilidade da rescisão da sentença de mérito fundada em transação inválida (cf. art. 485, inciso VIII) : não fora o julgamento correspondente alusivo à composição do litígio, jamais se poderia falar em tal espécie de ação rescisória, mas, somente, na ação anulatória prevista no subseqüente artigo 486.

Entendimento diferente, certamente equivocado, leva a admitir essa última espécie de atuação judicial, tal como tem acontecido em tribunais paulistas (cf. Rev. dos Tribs., vols. e págs. 564/118, 502/103, 496:101; Rev. de Jurispr. do TJESP, vols, e pags. 43/278, 42/266; julgados do TACSP (ed. Saraiva), vol. 75, pág. 83).

Afirmando-a ação adequada à desconstituição de ato judicial dependente de sentença homologatória, assim se expressou, e. g., a Sexta (6ª) Câmara do I Tribunal de Alçada Civil, no julgamento publicado na mencionada Rev. dos Tribs., vol. 564, à pág. 119: «... deparamos com típica sentença homologatória de transação, realizada em Juízo para extinguir o litígio (fls.). Nessas condições, a pretendida desconstituição há de ser feita na forma do art. 486 do CPC, tal como a requereu o apelante. Valendo-nos, neste passo, da lição de Barbosa Moreira, temos que os atos que constituem objeto da sentença homologatória 'apesar do invólucro sentencial que os cobre, podem ser diretamente impugnados, sem necessidade de rescindir-se - usada a palavra, aqui, na acepção técnica - a decisão homologatória' (ob. cit., p.186). Na elegante e precisa advertência de Costa Manso, 'a sentença limita-se a autenticar solenemente um ato das partes ou de terceira pessoa; não é , pois, a sentença, mas o próprio ato que se deve rescindir' (cit. por Barbosa Moreira, nota 240, p.185). Em recente julgamento, a C. $7^{\text {a }}$ Câmara deixou assentado, também, o cabimento da ação prevista no art. 486 do CPC para a rescisão de sentença homologatória de transação celebrada pelas partes (AI 287. 585)».

Bem é de ver, entretanto, que a alusão ao ensinamento de BARBOSA MOREIRA se apresenta de todo desfocada.

$\mathrm{O}$ acatado Mestre e Magistrado guanabarino trata da rescisão de sentença homologatória de transação em outra sede, e de modo bem diferente, como, aliás, reconhece o próprio acórdão, em parte anterior. $\mathrm{E}$ assim, corretamente, se expressa: «Pensamos, destarte, que é necessário distinguir, no tocante aos atos homologáveis por sentença entre os abrangidos pelo art. $458, n^{\circ}$ VIII, e os restantes. Com relação àqueles (renúncia à pretensão, reconhecimento do pedido, transação), o regime será análogo ao da confissão, tal como o define o art. 352; isto é: a ação anulatória unicamente poderá ser utilizada no curso do processo, antes do trânsito em julgado da sentença homologatória; 
depois disso, o remédio próprio e exclusivo será a ação rescisória do art. 485, $n^{\circ}$ VIII» (v. Comentários ao Código de Processo Civil, $4^{\mathrm{a}}$ ed., Rio de Janeiro, 1981, vol. V, págs. 188/189; com grifos, à exceção dos derradeiros, todos nossos).

E na esteira desse entendimento coloca-se a perfeita exegese dos apontados artigos 485, inciso VIII, e 486 do Código de Processo Civil, como evidenciado pelos Tribunais de Justiça do Estado do Paraná e de São Paulo in Rev. do Tribs., vols. e págs. 561/220 e 588/66.

O mais alto Pretório paulista, especialmente, nesse acórdão da lavra do eminente Desembargador ARRUDA ALVIM, clarifica: 《追 necessário estabelecer, apesar da pouca clareza da sistemática legal os limites entre o art. 485, VIII, e o art. 486, ambos do CPC. Parece que há de se convir que o mesmo sistema não pode ter dois caminhos preordenados a finalidades praticamente idênticas, quais sejam a rescisória fundada no art. 485, VIII, e a anulatória, calcada no art. 486, ambos do CPC. Em sendo assim, não disciplinam a mesma realidade. $\mathrm{O}$ art. 485, caput, endereça a ação rescisória contra sentenças de mérito e a transação julgada por sentença é representativa de que houve julgamento de mérito (art. 269, III), todos dispositivos do Código de Processo Civil».

A tônica da distinção questionada encontra-se, portanto, em que a sentença homologatória de transação, de renúncia ao direito material afirmado pelo autor ou de reconhecimento do pedido, pelo réu, da mesma maneira que o ato decisório de reconhecimento da prescrição ou da decadência, diz respeito ao meritum causae.

$\mathrm{E}$, assim sendo, obviamente que, quando proferimos previamente, correspondem, nà linguagem da lei, a julgamento antecipado da lide.

\section{Inadmissibilidade de condenação em honorários advocatíclos à falta de apelação adesiva do réu}

Ainda no tocante ao indeferimento liminar da petição inicial, faz por merecer consideração a hipótese em que, ocorrendo, seqüencialmente, a citação do réu, em virtude de apelação do autor e de acordo com o disposto do artigo 296 do Código de Processo Civil, venha este a constituir procurador judicial e pleitear, nas contra-razóes de recurso, a impasição ao demandante vencido dos ônus da sucumbência, inclusive a verba correspondente a honorários advocatícios.

Dos mais autorizados analistas da mencionada preceituação, o único a enfrentar, explicitamente, o tema é WELLINGTON MOREIRA PIMENTEL, Comentários ao Código de Processo Civil, Săo Paulo, 1975, vol. III, pág. 226, a saber: "Resta indagar o que ocorrerá se, havendo o rếu constituído advogado para acompanhar o recurso, e desprovido este, quanto aos honorários advocatícios despendidos pelo vencedor. Parece-nos que, em tal hipótese, o tribunal, ao negar provimento ao apelo do autor, imporá a este o pagamento das custás e dos hono- 
rários que, então, fixará tudo em conformidade com o art. 20 do Código».

Esse pronunciamento tem o endosso da Primeira (1 $\left.{ }^{\text {a }}\right)$ Turma do Supremo Tribunal Federal (v. Rev. Trim. de Jurispr., vol. 89, pág. 689; e Rev. dos Tribs., vol. 550, pág. 245) e de THEOTÔNIO NEGRÃO, op. cit. pág. 55 , nota 18 ao artigo 20 (este, por certo, em razão do entendimento manifestado à pág. 115 , in nota 31 ao artigo $267, \S 2^{\circ}$, no sentido de que o autor deve arcar com as custas e os honorários do advogado constituído pelo réu em todas as hipóteses de extinção do processo, sempre que vencido).

$\mathrm{E}$, pelo que se verifica do julgamento em referência, entende o Excelso Pretório ser caso de imposição ex officio, em grau de recurso, da verba honorária do patrono do demandado, verbis: «Extinto o processo pelo indeferimento da inicial, apelando o autor, e decaindo de sua intenção, uma vez observado o art. 296 do Código de Processo Civil, responde ele, como vencido, pelos honorários da sucumbência, art. 20, c/c o art. 28 e $267, \S 2^{\circ}$ do CPC».

Ousamos, todavia, dissentir dos eminentes autores citados e dos igualmente ilustres subscritores do acórdão indicado, como passamos a esclarecer.

Dúvida não pode haver acerca da dispensabilidade de pedido expresso para condenação em honorários advocatícios, como asseverado na Súmula $n^{\circ}$ 256, que, embora concebida à luz dos artigos 63 e 64 do Código de Processo Civil de 1939, subsiste na sua essencialidade por força do disposto no artigo 20 do atual (cf., e. g., Rev. For., vol. 261, pág. 270; Rev. de Jurispr. do TJESP, vol. 51, pág. 172).

Imperativa é, com efeito, a determinação do aludido artigo 20 , no início do caput "A sentença condenará $\mathbf{0}$ vencido...» (com grifos nossos).

Mas, como se tem, à evidência, desse mesmo dispositivo, o legislador nacional distingue, explicitamente, entre despesas e honorários advocatícios. $E$, ao referir-se, no $\S 1^{\circ}$ a recurso, limita a condenação do vencido às despesas: «...não em honorários, mas apenas nas despesas judiciais. Nos incidente e recursos, não cabe, portanto, a condenação em honorários» cf. THEOTÔNIO NEGRÃO, op. cit., pág. 54, nota 8 ao artigo $\left.20, \S 1^{\circ}\right)$.

Ademais, o $\S 2^{\circ}$ do mesmo artigo 20 define, criteriosamente, as despesas alvitradas no caput, como segue: «As despesas abrangem não só as custas do atos do processo, como também a indenização de viagem, diária de testemunha e remuneração do assistente técnico».

Nada mais do que isso, como patenteia CELSO AGRICOLA BARBI, Comentários ao Código de Processo Civil, Rio de Janeiro Sảo Paulo, 1975, vol. I, tomo I, págs. 189/190, ao estabelecer o «conceito legal de despesa», de sorte a tornar inaceitável qualquer interpre- 
tação extensiva (e, por não ter razão de ser, contraditória com a lei interpretada...), como quer PONTES DE MIRANDA, op. cit., $2^{a}$ ed., 1979, tomo I, pág. 532.

$\mathrm{E}$, por derradeiro, não se pode deixar de ter em conta, a tal propósito, a inadmissibilidade da reformatio in peius no sistema processual civil brasileiro em vigor, em que pese a inexistência de qualquer norma escrita proibitiva (cf. nosso Curso de Direito Processual Processo civil de conhecimento, II, São Paulo, 1976, págs. 246/247).

$\mathrm{Na}$ arguta observação de MOACYR AMARAL SANTOS, op. cit.,

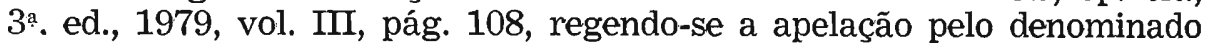
princípio dispositivo, o recorrente, normalmente, apela do que lhe é desfavorável na sentença. Isso, por certo, para obter solução mais favorável, sendo-lhe injusto, e até ilógico, que, recorrendo, veja piorar sua situação em benefício do adversário (a quem - permitimo-nos complementar, - é dado, também, impugnar a sentença para obter vantagem que não lhe tenha sido concedida).

Daí porque entendemos ser necessária apelacão adesiva do réu citado para contra-arrazoar o recurso do autor (na forma e prazo previstos no artigo 500 do Código de 1973), em prol da obtenção da verba honorária decorrente da confirmação da sentença indeferitória da petição inicial.

Como expressa JOSÉ CARLOS BARBOSA MOREIRA, Comentários et vol. cit., pág. 489, «A função do 'recurso adesivo' é justamente a de levar ao conhecimento do tribunal matéria que, só por força do recurso principal, não se devolveria».

\section{Conjugação do disposto no artigos 319 e 330, inciso $\mathrm{I}$, do Código de Processo Civil}

Já agora noutro diversificado aspecto, notório é que concebemos a contumácia, ou revelia, como «o não comparecimento em juízo da parte - autor, réu, ou ambos - omitindo-se totalmente a efetivação de suas pretensóes" (cf. nossos Da contumácia no processo civil brasileiro, São Paulo, 1964, pág. 123; e "Contumácia ou revelia», in Da ação e do processo civil na teoria e na prática, São Paulo, 1978, pág. 130).

Nesse mais recente escrito, já sob a vigência do Código de 1973, e em face do enunciado do artigo 319, cuidamos, também, de estabelecer, a par da genérica, a concepção de contumácia, ou revelia, em sentido estrito, correspondente ao descumprimento, pelo réu, do ônus de responder, deixando de contestar, no prazo legal, o pedido formulado pelo autor (cf., além do apontado, artigos 223 , $§ 1^{\circ}$. 255 , inciso II, e 285 , segunda parte).

Não nos encontramos isolados, no tocante ao entendimento assim manifestado. 
$\mathrm{E}$, dentre os que pensam de modo idêntico, cumpre destacar a opinião de JOSÉ JOAQUIM CALIMON DE PASSOS, Comentários ao Código de Processo Civil, $3^{\text {a }}$ ed., Rio de Janeiro, 1979, vol. III, pag. 246, após enfatizar que o Código não define a revelia, limitando-se a disciplinar seus efeitos, e verbis: "Como visto, a revelia ou contumácia pode ser referida tanto ao não-comparecimento da parte, em juízo, como à sua inatividade. O não-comparecimento é mais abrangente e inclui a inatividade, porquanto não age quem deixa de comparecer. Já a segunda é mais estrita. $\mathrm{O}$ art. 319 atribui os efeitos que enuncia ao não-comparecimento e ao comparecimento com inatividade. Se o réu, citado, constitui procurador nos autos, mas não contesta, ou o faz intempestivamente, os efeitos da revelia ocorrem no tocante aos fatos. Os que foram afirmados pelo autor serão reputados verdadeiros. Se o comparecimento, sem atuação, é relevante para os fins do art. 322, não o é para o previsto no art. 319».

Deve ser acrescentado que o artigo 319 em referência traduz o efeito material da revelia do demandado: a admissão, como verdadeiros, dos fatos alegados pelo autor, se inocorrente qualquer das situações previstas no subseqüente artigo 320 .

Como anota PONTES DE MIRANDA, op. cit., 1974, tomo IV, pág. 179, «O art. 319 redigiu a regra de dispensa abstrata da prova: se uma afirma e outra não nega, tem-se como verídica, sem necessidade de prova, a afirmação» (v., no mesmo sentido, a orientação jurisprudencial corrente, in Rev. For. vols. e págs. 247/157, 246/349; Rev. dos Tribs., vols. e págs. 538/234, 532/165, 520/163, 506/80, 505/234, Rev. de Jurispr. do TJESP, vol. 51, pág. 124; Julgados dos TACSP, vols. $56 / 102,55 / 111,38 / 40$ ).

Por outro lado, não pode deixar de ser levado em conta, também, seu efeito processual, determinado no artigo 330 , inciso II, e sobrelevado em nosso Do julgamento cit., págs. $257 / 259$, onde expressa, com THEOTÔNIO NEGRÃO, a cogência da regra, no caput, segundo o qual «O Juiz conhecerá diretamente do pedido, proferindo sentença...» (com grifo nosso): «Tenha-se presente, nesse particular, que o proferimento de ato decisório de mérito se torna decorrência inafastável da contumácia do demandado, exceto, é claro, quando ocorrer qualquer das situações expressamente ressalvadas na própria lei».

Daí porque, diferentemente do que tem sido, algumas vezes, propagado (v. Rev. Trim. de Jur., vol. 75, pág. 275; Rev. dos Tribs., vol. 563, pag. 216), o orgão jurisdicional deve conhecer, desde logo, do pedido e proferir sentença, sempre que o réu, devida e realmente citado, deixar de apresentar resposta ao pedido formulado pelo autor, no prazo legal (v., ainda, RITA GIANESINI, Da revelia no processo civil brasileiro, São Paulo, 1977, pág. 115; PONTES DE MIRANDA, Comentários cit., tomo IV, pág. 202; Rev. dos Tribs. vols. e págs. 520/162, 506/80, 493/162; Julgados dos TACPS, vol. 42, pág. 147). 
Isso não significa, contudo, que o julgamento seja, necessariamente, de acolhimento da pretensão deduzida no pedido formulado pelo autor, podendo, pelo contrário, ser-lhe adverso.

Mostra-o, em irrepreensível exegese dos preceitos a que alude, EDSON RIBAS MALACHINI, «Do julgamento conforme o estado do processo», in Revista Forense, Rio de Janeiro, 1978, vol. 261, pág. 416 (v., também, WELLINGTON MOREIRA PIMENTEL, op. et vol. cit., págs. 329/330; e SÉRGIO SAHIONE FADEL, op. et vol. cî́t., pág 541).

E reafirma-o correto entendimento jurisprudencial dos nossos Pretórios, publicizado in Rev. do Tribs. vols. e págs. 563/216, 536/116, 525/127/, 521/267, 520/140, 493/162; Rev. de Jurispr. do TJESP, vols. e págs. 50/139, 49/126; Julgados dos TACSP, vol. 45, pág. 190: «A revelia não tem o efeito de dar automático reconhecimento à procedência do pedido inicial» (da ementa do acórdão primeiramente mencionado).

O mais que se pode conceber, a tal propósito, como lembra RITA GIANESINI, op. cit., pags. 116/117, é a inadmissibilidade de proferimento de ato decisório de mérito à vista da não-concorrência, de pressuposto processual ou condição da ação. Caso contrário, o juiz tem o dever de julgar antecipadamente a lide.

\section{\%. Conseqüencias da revelia em sentido estrito na reconvenção}

Várias outras questões, altamente interessantes, como, e. g., a alusiva à aplicação, ou não, dos analisados artigos 319 e 330, inciso II, no âmbito da ação rescisória (v., a respeito, Rev. dos Tribs., vols. e págs. 571/163, 518/206; Julgados dos TACSP, vol. 49, pag. 56), poderiam constituir, igualmente, objeto deste lavor.

A sua já alentada extensão, todavia, não o permite, nesta oportunidade.

Fiquemos, por isso, para finalizar, no tema atinente à revelia em sentido estrito na reconvenção.

Expressa o artigo 316 do Código de Processo Civil que, apresentada pelo réu a demanda reconvencional, o autor-reconvindo deverá ser «intimado, na pessoa de seu procurador, para contestá-la no prazo de quinze (15) dias» (com grifos nossos).

Entendida, tal intimação, até (e, por certo, equivocamente) como citação (v. PONTES DE MIRANDA, op. cit., tomo IV, pág. 171; THEOTÓNIO NEGRÃO, op. cit., pág. 131, nota 2 ao artigo 316; Rev. Trim. de Jurispr., vol. 94, pag. 298), propende a maioria dos processualistas brasileiros para a incidência, também no âmbito da reconvenção, do artigo 319 , relativo, como visto, ao efeito material da revelia (v. JOSÉ JOAQUIM CALMON DE PASSOS, op. et vol. cit., pags. 439/440; CLITO FORNACTARI JÚNIOR, Da reconvencão no Direito Processual Civil Brasileiro, São Paulo, 1979, págs. 181/182; JACY DE 
ASSIS, Procedimento ordinário, São Paulo, 1975, pág. 107; MARCOS AFONSO BORGES, op. et vol. cit., pág. 327; RITA GIANESINI, op. cit., págs. 144/145).

Essa foi, aliás, a XXVIIa. Conclusão do Simpósio de Curitiba, em 1975, contra o nosso voto, que ousamos reafirmar.

Com efeito, ocorre, então, como bem explica JOSÉ FREDERICO MARQUES, op. et vol. cit, pags. 94/95, apenas o «descumprimento de ônus sobre a impugnação específica das quaestiones facti», havendo lugar, isso sim, para a incidência da regra contida no artigo 302 .

Mesmo porque, na realidade, não há, aí, a citação, pessoal e válida, do autor-reconvindo cf. Rev. dos Tribs., vol. 470, pág. 113), e, muitas e muitas vezes, o procurador não tem, sequer, poderes para recebê-la ou lhe falta, na experiente observação de JACY DE ASSIS, Comentários ao Código de Processo Civil, Rio de Janeiro, 1979, vol. II, tomo II, pág. 246, «conhecimento dos motivos do pedido reconvencional» ou a possibilidade de «encontrar-se com seu mandante para formular a contestação e impugnar os fatos, de maneira específica».

Ademais, profunda desigualdade mostra-se no tratamento dispensado ao autor-reconvido, em tal circunstância (dada a inaplicação, relativamente a ele, do disposto nos artigos $223, \S 1^{\circ}$, 225 , inciso II, e 285 , última parte), com flagrante violação do denominado princípio da isonomia processual.

Finalmente, como aduz CALMON DE PASSOS, op. et vol. cit.s pag. 440, devendo a ação e a reconvenção serem julgadas numa só sentença (cf. o teor do artigo 318 do Código de 1973), incidível resta, sem dúvida, a instrução da causa, devendo ser levada em consideração, pelo juiz, a prova produzida, de sorte que seu convencimento seja «coerente e único em relação aos fatos que sejam relevantes e pertinentes para ambas as ações, pouco importando tenham eles sido comprovados em função da demanda principal ou do litígio reconvencional». Via de conseqüência - permitimo-nos acrescentar, - incogitável delineia-se o efeito processual da revelia em sentido estrito, na reconvenção, pois o julgamento antecipado da lide somente pode ocorrer se o juiz estiver apto a decidir de plano ambas as lides - a da ação principal e a reconvencional (cf. CLITO FORNECIARI JÚNIOR, op. cit., pag. 190; WELLINGTON MOREIRA PIMENTEL, op. et. vol. cit., pág. 325; JACY DE ASSIS, Comentários, vol. et tomo cit., pág. 249; LUIS ANTÔNIO DE ANDRADE, op. cit., pág. 150; MARCOS AFONSO BORGES, op. et vol. cit., págs. 328/329; Rev. dos Tribs., vol. 567, pág. 127).

\section{Conclusões}

Ante todo o expendido, parece-nos correto estabelecer as seguintes conclusões, referentemente aos temas versados neste breve estudo: 
Primeira) O julgamento conforme o estado do processo divide-se, apenas, em julgamento segundo o estado dos autos e julgamento antecipado da lide, ambos mediante sentença que põe termo ao processo, respectivamente, sem e com exame do meritum causae.

Não compreende, portanto, o ato decisório de saneamento do processo, da natureza interlocutória, pela qual «o juiz, verificando ser admissível a ação a regular o processo, o impele em direção à audiência, por não estar madura a causa para o julgamento do mérito» (cf. JOSÉ CARLOS BARBOSA MOREIRA, O novo processo civil brasileiro cit., pág. 153).

Segunda) 0 indeferimento liminar da petição inicial dá-se, em regra, através de sentença em que o juiz ou tribunal extingue o processo sem julgamento do mérito.

Essa modalidade de julgamento segundo o estado dos autos explica-se por ter o processo iniciada sua formação com o ajuizamento da ação, «tanto que a petição inicial seja despachada pelo juiz, ou simplesmente distribuida, onde houver mais de uma vara» (cf. artigo 263, primeira parte, do Código de Processo Civil), assim também, no primeiro caso, quando «protocolada, se o magistrado estiver ausente» (cf. THEOTONIO NEGRÃO, op. cit., pág. 111, nota 2 ao apontado artigo 263).

Terceira) A indicação do artigo 329, segunda parte, do Código de Processo Civil revela a previsão de julgamento antecipado da lide, não só nas circunstâncias alvitradas no artigo 330, como, por igual, em se tratando de reconhecimento da procedência do pedido, pelo réu, de transação, de pronunciação da decadência ou da prescrição ou de renúncia, pelo autor, ao direito sobre que se funda a ação - casos em que ocorre a extinção do processo com julgamento do mérito (cf. artigo 269, incisos II a V).

Conseqüentemente, a sentença homologatória de reconhecimento do pedido, de transação ou de renúncia à pretensão, da mesma maneira que $o$ ato decisório de reconhecimento da decadência ou da prescrição, diz respeito ao mérito da causa, consistindo, portanto, num ato compositivo da lide submetida à apreciação judicial.

Quarta) indeferida liminarmente a petição inicial, e havendo apelação do autor, o tribunal não pode impor-lhe, ex-officio, a condenação no pagamento dos honorários de advogado constituído pelo réu, citado para acompanhar o recurso, nos termos do disposto no artigo 296 do Código de Processo Civil.

Impedem-no, a par da proibicão da «reformato in peius», no vigorante sistema processual civil brasileiro, as preceituações contidas nos $\S \S 1^{\circ}$ e $2^{\circ}$ do artigo 20 do mesmo Diploma legal, de sorte a tornar necessária, em prol da obtenção da verba honorária decorrente da 
confirmação da sentença indeferitória da petição inicial, a interposição de recurso adesivo, pelo réu.

Quinta) A revelia em sentido estrito, ou seja, a decorrente da falta de resposta do réu (devida e realmente citado) ao pedido formulado pelo autor, no prazo legal, produz dois efeitos - um material, previsto no artigo 319 do Código de Processo Civil, segundo o qual, em regra, se reputam verdadeiros os fatos alegados pelo demandante, e não contestados pelo demandado; e outro processual, prescrito no artigo 330, inciso II, determinante do julgamento antecipado da lide.

Este, todavia, pode ser tanto favorável, como desfavorável, ao autor beneficiado pela omissão do réu, pois, embora adstrito aos fatos afirmados pelas partes, «é da atribuição do juiz conhecer da matéria de direito, sem que nessa parte se encontre vinculado e embaraçado pela atitude dos litigantes» (cf. JOSÉ ALBERTO DOS REIS, Breve estudo sobre a reforma do processo civil e comercial, $2^{\text {a }}$ ed., Coimbra, 1929, pág. 119).

Reafirma-se, aí, induvidosamente, o vigor de aforismas que se tradicionalizam no âmbito do Direito Processual, a saber: «Narra mihi factum dabo tibi ius» e "Iura novit curia».

Sexta) Inaplicável afigura-se o disposto no artigo 319 do Código de Processo Civil, referentemente à revelia em sentido estrito do autorreconvindo, na reconvenção.

Ocorre, então, segundo preciso ensinamento de JOSÉ FREDERICO MARQUES, op. et vol. cit., págs. 94/95, apenas o descumprimento do ônus da impugnação especificada dos fatos, com as conseqüências estabelecidas no artigo 302.

$\mathrm{E}$, de resto, não há como cogitar-se, em tal caso, da incidência do efeito processual da revelia, até porque, por força da regra estabelecida no artigo 318, ação e reconvenção devem ser julgadas, antecipadamente ou não, numa só sentença. 